\title{
Surrounding Factors' Influence on the Accuracy of the Digital Level and Total Station
}

\author{
Israa. A. Al-Qabas*, Magda. H. Farahan and Hossam El-Din Fawzy \\ Civil Department, Faculty of Engineering, Kafr El-Sheikh University, Egypt \\ *Corresponding author graduate student : israa.alqabas@gmail.com
}

Submitted: $20 / 02 / 2019$

Revised: $\quad 25 / 03 / 2020$

Accepted: $24 / 04 / 2020$

\begin{abstract}
The digital level (SOKKIA SDL-30) and total station (SOKKIA CX-105) are highlighted as examples of digital surveying instruments. In this study, it is clarified how some surrounding factors can affect their efficiency such as vibration, sunlight, and its direction, temperature, and battery capacity. Through vibration testing as one of these factors ,both the digital level and the total station using the reflector-less were exposed to vibration up to $25 \mathrm{KHZ} / \mathrm{Sec}$, the average and the standard deviations elevation error for the digital level increased by 2 times at $80 \mathrm{~m}$ distance, and the average and the standard deviations positioning error increased 3 times for the total station using the reflector-less total at $80 \mathrm{~m}$ distance between the instrument and bar code. $64.3 \%$ and $51.25 \%$ are the increasing ratios in average error for digital level and total station with reflector-less prism by testing the effect of sunlight and its position. The increase in temperature leads to an increase in the average error with $150 \%$ and $66.6 \%$ for digital level and reflectorless total station. Finally, the lack of battery efficiency led to a shortage of accuracy of the Surveying Instruments.
\end{abstract}

Keywords: Vibration; Temperature; Sunlight position; Battery Charge; Accuracy.

\section{INTRODUCTION}

Digital surveying instruments have a unique function in construction process, which is not done accurately without them. Saving time and effort are both characteristics of these instruments and even if these digital devices are efficient, they cannot eliminate these errors completely due to some external influences surrounding them such as vibrations, which take place in sites with heavy equipment and when the devices exist on the bridges through the observation process or when they happen next to the railways. This happens even with a compensator inside these digital devices (Ko \& Ni, 2003). Sunlight and its direction also cause a change in the accuracy of digital instruments, and also climate conditions as wind, moisture (Gassner, 2005), (Pellegrinelli, Furini, Bonfè \& Russo, 2013), and temperature (Pašagić \& Risović, 2003). Whether it increases or decreases, it affects the efficiency of these instruments (Gucević, J., Delčev, S., \& Ogrizović, V., 2011), (Kowalczyk \& Rapinski, 2014). Several studies in the last decade discussed different conditions affecting the geodetic measurements accuracy, which was illustrated and highlighted in a few paragraphs. Kudryavtsev, Kazharsky, Yedigaryan \& Goncharova (2018) monitored two levels for car parking, which is placed in Khabarovsk town. The shortage of pile has been modelled to get rid of the deviation of horizontal measurements because Earth is spherical. The results concluded that well designed reinforcement is needed in construction process. Moreover, atmospheric parameters have been studied by Murariu, Hahuie \& Georgescu (2017), and the results concluded that the air pressure, relative humidity, and temperature are the main parameters 
that effect the accuracy of the instruments. Gucević, J., Delčev, S., \& Ogrizović, V. (2011) investigated the effect of temperature at low levels on the digital levels, and the results concluded that the error can be restricted by adding corrective values. As the temperature changed, the rod must be tripod. The correction must be calculated and added to the values to ensure high level of accuracy. Geethalankara, Rupasinghe \& Niriella (2016) studied the parameters affecting the observations accuracy of reflector-less Total Station. The results referred to there were a conversion in the accuracy for short distances. The maximal observation reached $35 \mathrm{~m}$. The angle of inclination should be restricted with $30^{\circ}$. Pašagić \& Risović (2003) studied the effect of the pressure and temperature on the surveying instruments. The conclusion for this study focused on evaluating the resolution of telescope based on atmosphere depending on the range of how far is the measured object besides the effect of both temperature and pressure. Arseni, Georgescu \& Circiumaru (2015) studied the Total Station (Model Leica TC(R) -705) accuracy when affected by temperature change at different distances. The results concluded that there was a significant effect on the accuracy with changing the temperature. There is a need to apply a correction factor to the readings when the temperature of the surrounding changes. A 8-10 mm error was noticed when 350-500 m distance was measured when the temperature ranged from 25 to $30^{\circ} \mathrm{C}$. The effect of sun besides the effect of battery capacity has been studied by Beshr \& Abo Elnaga (2011). The results referred to the fact that the time of observation besides the precise appearance of the Digital level could be enhanced by $10-15 \%$. Moreover, the observation's average error increased by $30-35 \%$ when the telescope is positioned in the sunlight direction. Elhassan \&Ali (2011) studied the difference between the optical and digital levels on measuring the distances. The results concluded that the accuracy of the optical levels reaches 1/4000 and 1/5000. The accuracy obtained using SDL30 digital level reaches 1/10000. The measured distance reaches 100m with 1:4000 accuracy. Based on the literature review, it can be clearly noticed that there are few researches conducted to investigate the effect of battery level besides high temperatures levels on the accuracy of the geodetic measurements especially digital level and total station level instruments.

Therefore, we have done some tests to study the effect of the surrounding factors on the digital surveying instruments, and we will explain that in the next paragraphs.

\section{METHODOLOGY}

This research indicates experimentally the impact of some important factors (i.e., Sunlight and vibration) on the accuracy of digital level (SOKKIA SDL-30) and total station (SOKKIA CX-105) as digital surveying instruments. Vibrations effect on the accuracy of those two mentioned instruments was studied in two cases (i.e., without vibrations and with an artificial vibration). The batteries were kept fully charged before observation process, and instruments were adjusted horizontality to maintain horizontal line-of-sight. There is no doubt that it is better to depend on the real source of vibrations (i.e., railways and construction sites), but they are not reliable; instead, artificial vibration has been used in recent work. Vibrations were generated by a set of 3 DC motors, which were controlled by vibration sensor (SW-420) and Arduino chipset. The observations were recorded at equal different distances every 5 meters to 100 meters. At each distance, 20 observations were taken to calculate their average error and the standard deviation error. Moreover, the effect of sunlight direction on the accuracy of those two mentioned instruments was studied in two cases (i.e., with and against the direction of sunlight). Firstly, the instruments were adjusted horizontality to maintain a horizontal line-of-sight with full battery. The observations were recorded at equal distances every 10 meters to 100 meters and every 10 meters. At each record, 20 observations were recorded to calculate the average error and the standard deviation error. On the other hand, the effect of temperature on digital instruments was also conducted in recent work. To insure controlled experiment, this test was performed in the laboratory changing the temperature from $17^{\circ} \mathrm{C}$ to $50{ }^{\circ} \mathrm{C}$ recording the observation every three degrees with fully charged battery at fixed observed distance rating 50 meters. The temperature was measured by a digital thermometer and was controlled by a radiator. 20 observations were recorded at each observation to calculate the average error and the standard deviation error. Furthermore, the effect of the battery charge on the accuracy of digital instruments was studied. The instruments were adjusted horizontality, while the measurements were recorded every 30 mins till 8 hours at constant distance rating 
$50 \mathrm{~m}$ between the digital level and the coded staff. The total station measurements were recorded every $30 \mathrm{~min}$ for 6 hours for $50 \mathrm{~m}$ with equal distances $10 \mathrm{~m}$ interval between the total station and the reflector-less. 20 observations were recorded at each distance to calculate their average error and the standard deviation error for these observations. Additionally, the average error and standard deviation error of elevation observations were calculated as reported by Glaser \& Triston (2004) and Teunissen\& Amiri-Simkooei (2007) as follows:

We calculated the average error and standard deviation error of elevation observations resulting from the digital level:

$V_{i(i=1,2, \ldots ., n)}=\mid X_{i}-X Y$

$\max .(\text { elev. })_{\text {error }}=\operatorname{Maximum}\left(V_{i}\right) \quad \min .(\text { elev. })_{\text {error }}=\operatorname{Minimum}\left(\mathrm{V}_{\mathrm{i}}\right)$

avg. (elev. $)_{\text {error }}=\frac{\sum_{i=1}^{\mathrm{n}} \mathrm{v}_{\mathrm{i}}}{\mathrm{n}} \quad \sigma_{\mathrm{x}}= \pm \sqrt{\frac{\sum_{\mathrm{i}=1}^{\mathrm{n}} \mathrm{v}_{\mathrm{i}}^{2}}{\mathrm{n}-1}}$

where

$\mathrm{V}_{\mathrm{i}(\mathrm{i}=1,2, \ldots ., \mathrm{n})}=$ the absolute error of elevation on staff reading after exposure to vibrations

$\mathrm{n}=$ the number of staff readings ( 25 times).

$\mathrm{X}_{\mathrm{i}}=$ the staff reading after exposure to vibrations

$\mathrm{X}^{\backslash}=$ the average staff reading (before exposure to vibrations)

max. (elev. $)_{\text {error }}=$ The absolute maximum error of elevation.

min. (elev. $)_{\text {error }}=$ The absolute minimum error of elevation.

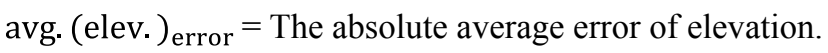

$\sigma_{\mathrm{x}}=$ the standard deviation error of elevation observations.

We calculated the average positioning error and standard deviation error of positioning:

$V_{i(i=1,2, \ldots ., n)}=\sqrt{\left(X_{i}-X \backslash\right)^{2}+\left(Y_{i}-Y \backslash\right)^{2}+\left(Z_{i}-Z \backslash\right)^{2}}$

avg. (Pos.) $)_{\text {error }}=\frac{\sum_{\mathrm{i}=1}^{\mathrm{n}} \mathbf{v}_{\mathrm{i}}}{\mathrm{n}} \quad \sigma_{\text {Pos. }}= \pm \sqrt{\frac{\sum_{\mathrm{i}=1}^{\mathrm{n}} \mathrm{v}_{\mathrm{i}}^{2}}{\mathrm{n}-1}}$

$V_{i(i=1,2, \ldots ., n)}=$ the error of positioning on observation after exposure to vibrations

$\mathrm{n}=$ the number of observation (25 times).

$\mathrm{X}_{\mathrm{i}}, \mathrm{Y}_{\mathrm{i}} \& \mathrm{Z}_{\mathrm{i}}=$ the Easting, Northing and Elevation of observation after exposure to vibrations

$\mathrm{X} \backslash, \mathrm{Y} \backslash \& \mathrm{Z} \backslash=$ the average Easting, Northing and Elevation of observation (before exposure to vibrations)

avg. (Pos. $)$ error $=$ The absolute average error of positioning.

$\sigma_{\text {Pos. }}=$ the standard deviation error of positioning observations

Nevertheless, before we will show the specifications of the digital level devices (SOKKIA SDL- 30), the total station (SOKKIA CX-105). 


\section{Digital level}

The digital level (SOKKIA SDL-30) with the specification illustrated in table 1 and its photo in figure 1(a) is followed by several experimental investigations as illustrated in the paragraphs below.

Table 1. Digital Level (SOKKIA SDL- 30) Specs.

\begin{tabular}{llll}
\hline item & \multicolumn{2}{l}{ specification } & \\
\hline Accuracy & $1 \mathrm{~mm}$ Standard dev. for $1000 \mathrm{~m}$ double run levelling \\
Accuracy of distance & $<10 \mathrm{~m} \quad$ From $(10$ to 50$) \mathrm{m}$ & $>50 \mathrm{~m}$ \\
& $+/-10 \mathrm{~mm} \quad+/-0.1 \% \mathrm{xD}$ & $0.2 \% \mathrm{xD}$ \\
Display resolution & $.0001 / .001 \mathrm{~m}$ & \\
Range of measuring & 1.6 to $100 \mathrm{~m}$ & \\
Zooming & $32 \mathrm{x}$ \\
Storage & 2000 points \\
Communications & $\mathrm{RS}-232 \mathrm{C}$ \\
Water resistance & $\mathrm{IPX} 4$ \\
Temp. of Operation & $(-20 \text { to }+50)^{\circ} \mathrm{C}$ \\
Operating period & More than 8.5 hours \\
\hline
\end{tabular}

\section{Total station}

The total station (SOKKIA CX-105) shown in Figure 1(b) with specification tabulated in table 2 is chosen in this study to be tested as mentioned in the next paragraphs.

Table 2. SOKKIA CX-105 Total Specs.

\begin{tabular}{ll}
\hline item & specification \\
\hline Resolution of display & $1 " / 5^{\prime \prime}(0.0002 / 0.001$ gon, $0.005 / 0.02 \mathrm{mil})$ \\
Accuracy & $5^{\prime \prime}$ \\
Laser beam (Reflector-less mode) & Class $3 \mathrm{R} /$ Prism / sheet mode: Class 1 \\
Range reflector-less mode & 0.3 to $500 \mathrm{~m}$ \\
Range prism mode & $1.3 \mathrm{~m}$ to $4,000 \mathrm{~m} /$ Under good conditions: to $5,000 \mathrm{~m}$ \\
Display Resolution & Fine/Rapid: $0.001 \mathrm{~m} / 0.01 \mathrm{ft} . / 1 / 8$ in. Tracking $0.01 \mathrm{~m} / 0.1 \mathrm{ft} . / 1 / 2 \mathrm{in}$. \\
Accuracy & Reflector-less: $(3+2 \mathrm{ppm} \times \mathrm{D}) \mathrm{mm}$ \\
& Prism Mode: $(2+2 \mathrm{ppm} \times \mathrm{D}) \mathrm{mm}$ \\
Zooming in & $30 \mathrm{x}$ \\
Data Storage & Approx. 10,000 points Internal storage. \\
Communications & USB memory \\
Operating Temperature & $\left(-20^{\circ} \mathrm{Cto}+50^{\circ} \mathrm{C}\right.$ \\
Operating Time & 36 hrs. Approx. \\
\hline
\end{tabular}




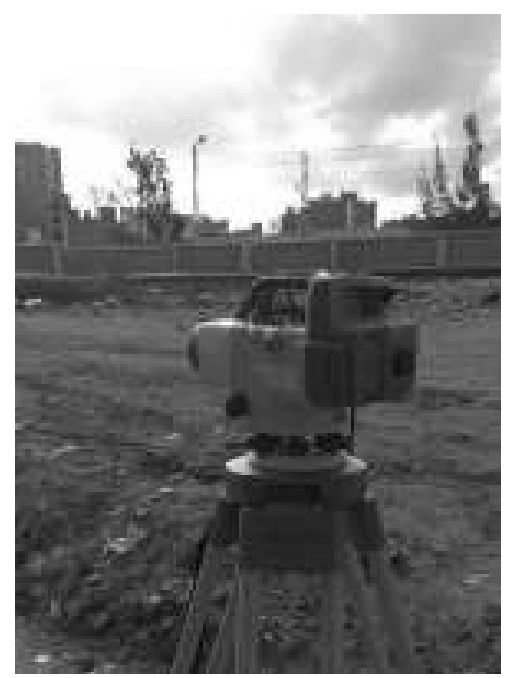

(a)

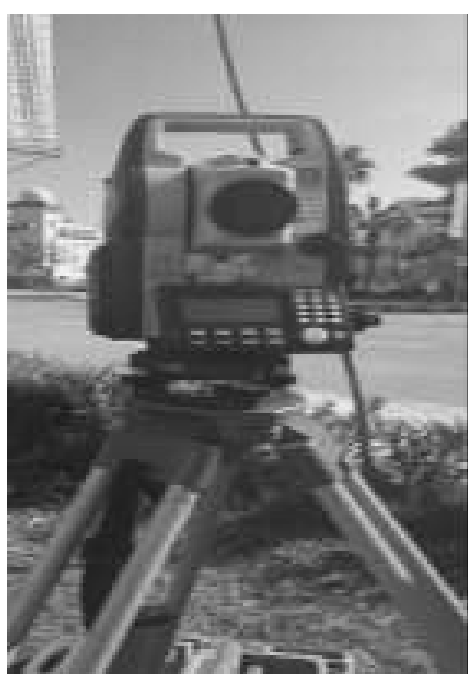

(b)

Figure 1. Photo for both instruments within the experiments.

\section{Vibration Test}

Vibration is a factor that has a strong influence on the accuracy of observations; these vibrations, which take place in sites with heavy equipment and are also caused due to wind or noise or when the devices exist on the bridges through the observation process or when it happens next to the railways, affect the accuracy of observation results because the vibration caused changes in the instruments horizontal plane, although digital surveying instruments contain a pendulum compensator that is used to maintain the instrument horizon. The compensator works to correct the optical path depending on the gravitational property and the optical pathway to its horizontal plane, after an operator completes the levelling with a bull's eye bubble, but it works within a very small field (Nasreldin, 2018; Algarni \& Ali, 1998). Vibrations consist of a set of frequencies measured by $\mathrm{Hz}$ (Li, Tan \& Wang, 2018).

Among the many different ways to measure the vibration (Kim, Kwon \& Kim, 2013), we used a vibration sensor (SW-420); this sensor can be connected to Arduino hardware (Yadesh \& Venkatachalam, 2016; Nasution, Muchtar \& Siregar, 2017). Arduino is an easy program, from which we can use a microcontroller board called Arduino Uno. It is a microcontroller board (Patel, 2017; Zhao, Li, \& Liu, 2018.) that can be connected to a computer Universal Serial Bus (USB) as indicated in Figure 2 to display the vibration values in Hertz by Second unit using the code of (SW-420) sensor shown in Figure 3.

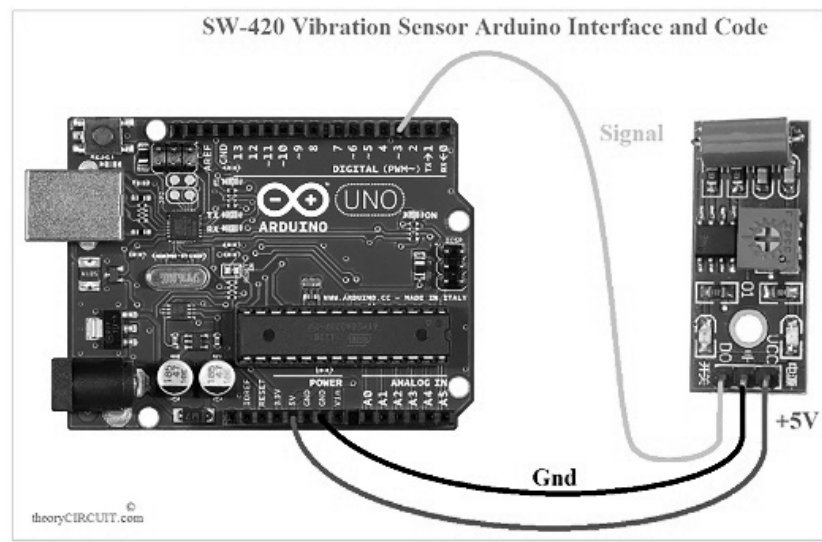

Figure 2. SW-420 Sensor Connected to Uno Board. 

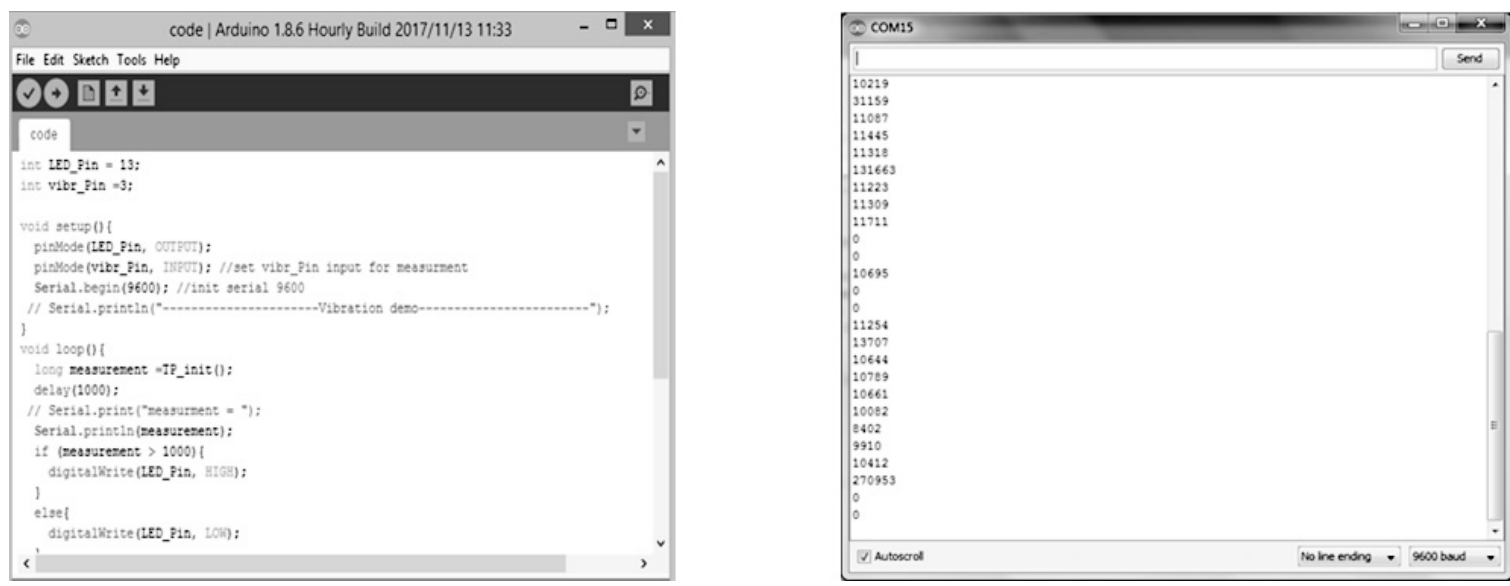

Figure 3. Display the code of SW-420 sensor connected to Arduino software to present the vibration values in Hertz by Second unit.

The test took place in several places such as bridges, railways, and construction sites with heavy equipment and with measuring the value of the vibration frequencies on the Digital level with the help of SW-420 Arduino. We calculated the real vibration value, which was from $(5000$ to 15000 Hertz per second to know the natural vibration range (Jeon, Kim, \& Kim. 2015.). But with the workflow and hard conditions surrounding, we simulated the vibration system by connecting the tripod of digital level by 3 DC motor on each leg of the tripod, which represents the vibrations affecting the device inside the simulation system. We generated artificial vibrations in two stages from 0 to $12,500 \mathrm{~Hz}$ and from 12,500 to $25,000 \mathrm{~Hz}$. These results were determined by the vibration sensor SW-420, which was connected to Arduino Hardware to measure the vibration that affects the digital surveying instruments. Two tests were carried out; the first was by using Sokkia digital level SDL-30 with fully charged battery during the daytime under natural light and temperature of $25^{\circ} \mathrm{C}$ outdoors; it was adjusted horizontally and recorded the average error of 20 staff reading without vibration and once again was exposed to vibration through two stages at equal distances every 5 meters up to 100 meters.

\section{Sunlight Direction Test}

Two tests were carried out using the digital level (Sokkia SDL30) and the total station with the reflector-less (SOKKIA CX-105) with fully charged battery during daytime under natural light and temperature of $25^{\circ} \mathrm{C}$ outdoors. They were adjusted horizontally, and the observations were recorded for both digital level and total station in the sun direction and in the opposite one at equal distances every 10 meters up to 80 meters for digital level, and the average was recorded for 10 staff reading on the other side. 10 observations were recorded with the positioning up to every 10 meters 100 meters for total station.

\section{Temperature Test}

Two tests were carried out using the digital level (Sokkia SDL30) and the total station with the reflector-less (SOKKIA CX-105) with fully charged battery in the laboratory and in order to control the temperature inside the laboratory, we used a space heater. Temperature was set from $17{ }^{\circ} \mathrm{C}$ to $50^{\circ} \mathrm{C}$. In addition, a digital thermometer was used to measure the temperature. The distance between each instrument and the target was $50 \mathrm{~m}$. Measurements were recorded at every change in temperature by $3{ }^{\circ} \mathrm{C}$.

\section{Battery Charge Test}

Two tests were carried out using the digital level (Sokkia SDL30) and the total station with the reflector-less (SOKKIA CX-105) with fully charged battery, and they were adjusted horizontally. Measurements were recorded 
every $30 \mathrm{~min}$ for 8 hours for $50 \mathrm{~m}$ with equal distances $10 \mathrm{~m}$ interval between the digital level and the coded staff and for the total station, measurements were recorded every $30 \mathrm{~min}$ for 6 hours for $50 \mathrm{~m}$ with equal distances $10 \mathrm{~m}$ interval between the total station and the reflector-less.

\section{RESULT AND DISCUSSION}

\section{Vibration Test result}

The first case of the test was without exposing the digital level or the total station to any artificial vibration. Figure 4 illustrates the elevation average error and standard deviation elevation error for digital level without vibration.

It looks through Figure 4 that the average elevation error and standard deviation elevation error increase with increasing the horizontal distance. $14.22,7.57 \mathrm{~mm}$ were the elevation average error and standard deviation elevation error for $90 \mathrm{~m}$ distance.
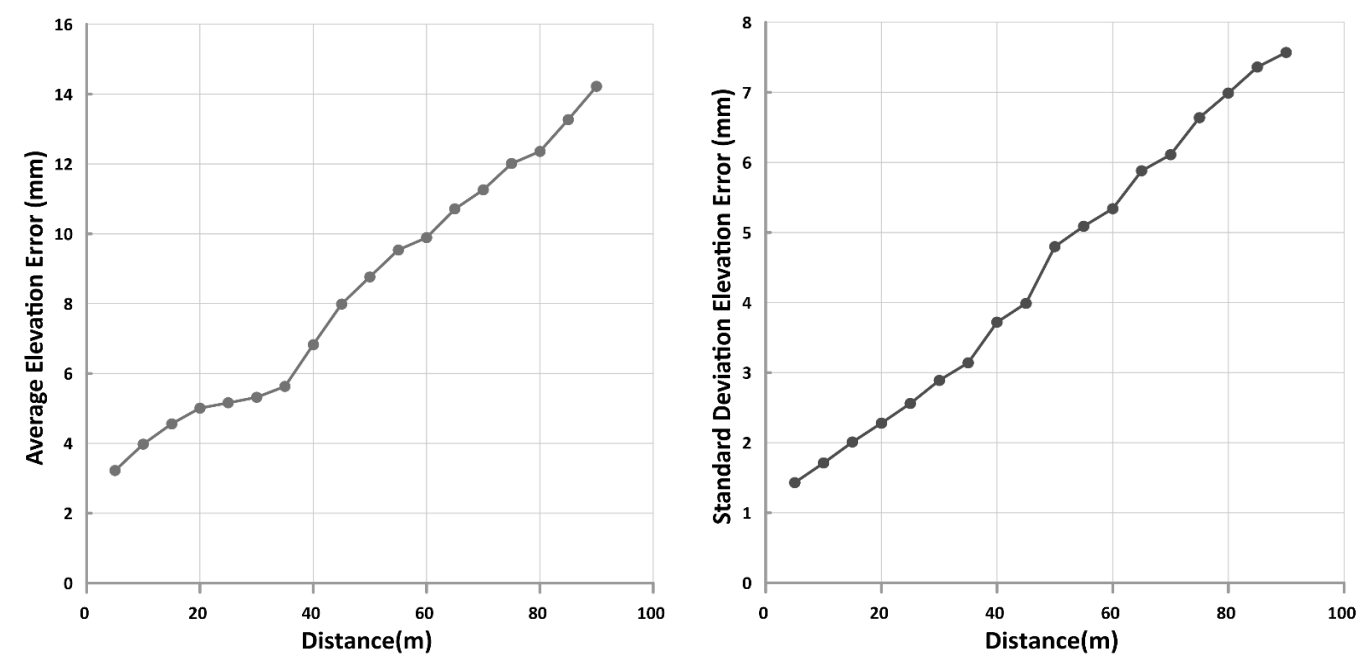

Figure 4. The Average Elevation and Standard deviation Error of digital level observations at different distances.

The trend line equations, correlation, and the coefficient of determination were calculated for each chart and each condition of observation as shown below in table 3. But before displaying these equations, we must first define these terms: the trend line is a line on a chart showing the common direction that a group of points seem to follow; correlation is a statistical technique, which can show how strong pairs of variables are related; and the coefficient of determination, denoted by $\mathrm{R} 2$ or $\mathrm{r} 2$ and pronounced "R squared", is the proportion of the variance in the dependent variable that is predictable from the independent variable(s). The correlation coefficient $(\mathrm{R})$ ranges from -1.0 to +1.0 . The closer the $\mathrm{R}$ is to +1 or -1 , the more close the two variables are related.

Table 3. The trend line equations, correlation, and the coefficient of determination for observations error resulting from the chart.

\begin{tabular}{|c|c|c|c|}
\hline $\begin{array}{c}\text { Observations } \\
\text { conditions }\end{array}$ & $\begin{array}{c}\text { Trend line equations of errors, where } \mathbf{D} \text { is } \\
\text { Distance in }(\mathbf{m})\end{array}$ & $\begin{array}{c}\text { The correlation } \\
\text { between Distance } \\
\text { and the average } \\
\text { elevation error }\end{array}$ & $\begin{array}{c}\text { Coefficient of } \\
\text { determination }\end{array}$ \\
\hline $\begin{array}{c}\text { Without } \\
\text { Vibration }\end{array}$ & Error $=(2.1655+0.1295 \mathrm{D}) \mathrm{mm}$ & $\mathrm{R}=0.992$ & $\mathrm{R}^{2}=0.98$ \\
\hline
\end{tabular}



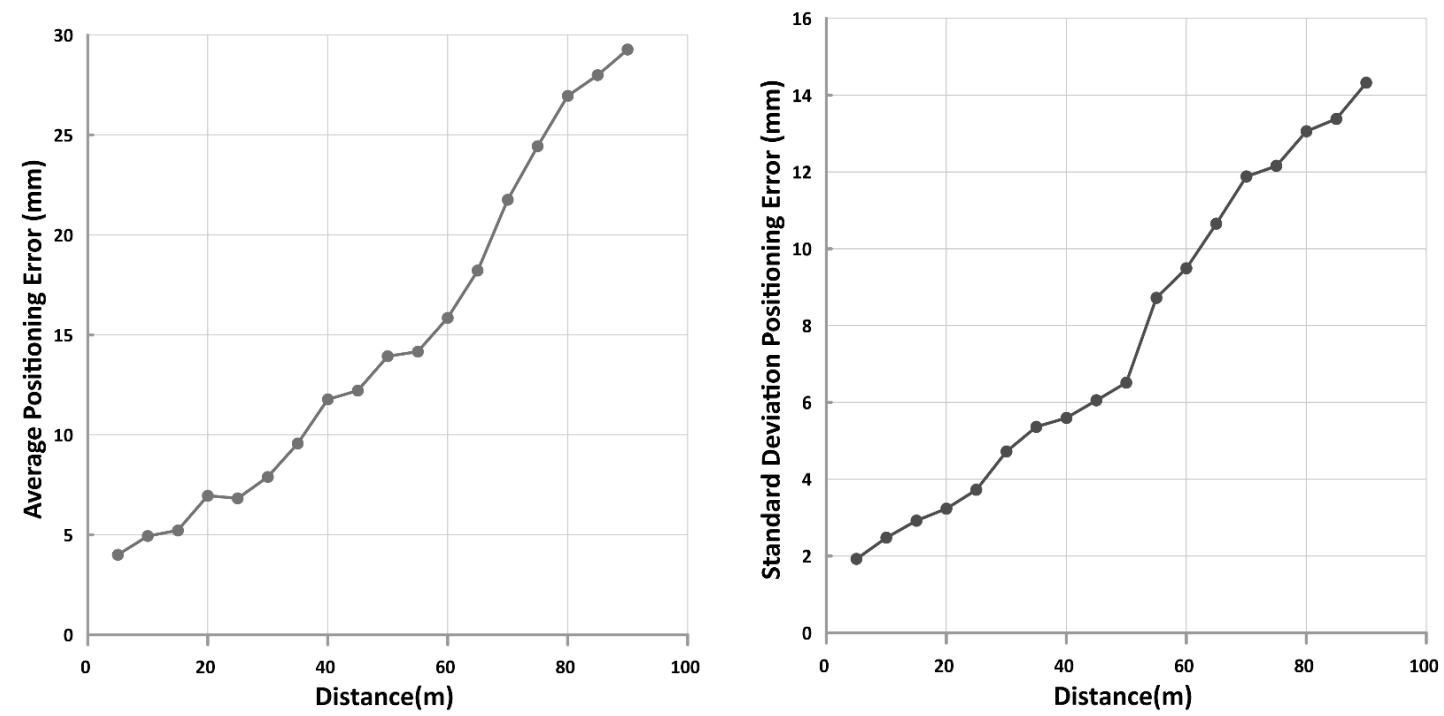

Figure 5. A reflector-less prism Average and Standard deviations error observations without vibrations at different distances.

Figures 5 shows the average and standard deviations of positioning observations using the reflector-less prism without vibration. 29.27, $14.32 \mathrm{~mm}$ were the maximum values at $90 \mathrm{~m}$. The average elevation error and standard deviation elevation error increase with increasing the horizontal distance.

The trend line equation, correlation, and the coefficient of determination for charts for each condition are shown in table 4.

Table 4. The trend line equations, correlation, and the coefficient of determination for observations error resulting from the chart.

\begin{tabular}{|c|c|c|c|}
\hline $\begin{array}{c}\text { Observations } \\
\text { conditions }\end{array}$ & $\begin{array}{c}\text { Trend line equations of errors, where D is } \\
\text { Distance in }(\mathbf{m})\end{array}$ & $\begin{array}{c}\text { The correlation between } \\
\text { Distance and the average } \\
\text { positioning error }\end{array}$ & $\begin{array}{c}\text { Coefficient of } \\
\text { determination }\end{array}$ \\
\hline $\begin{array}{c}\text { Without } \\
\text { Vibration }\end{array}$ & Error $=(0.1243+0.309 \mathrm{D}) \mathrm{mm}$ & $\mathrm{R}=0.9789$ & $\mathrm{R}^{2}=0.9583$ \\
\hline
\end{tabular}

The second case of the test with artificial vibration Figure 6 illustrates the elevation average error and standard deviation error for digital level within two vibration stages: from 0 to $12500 \mathrm{HZ} / \mathrm{Sec}$. and from 12500 to 25000 $\mathrm{HZ} / \mathrm{Sec}$. Figure 6 also shows that as the vibration increases, the observation distance limit decreases and with the experiment, it is found that it has a certain limit. 

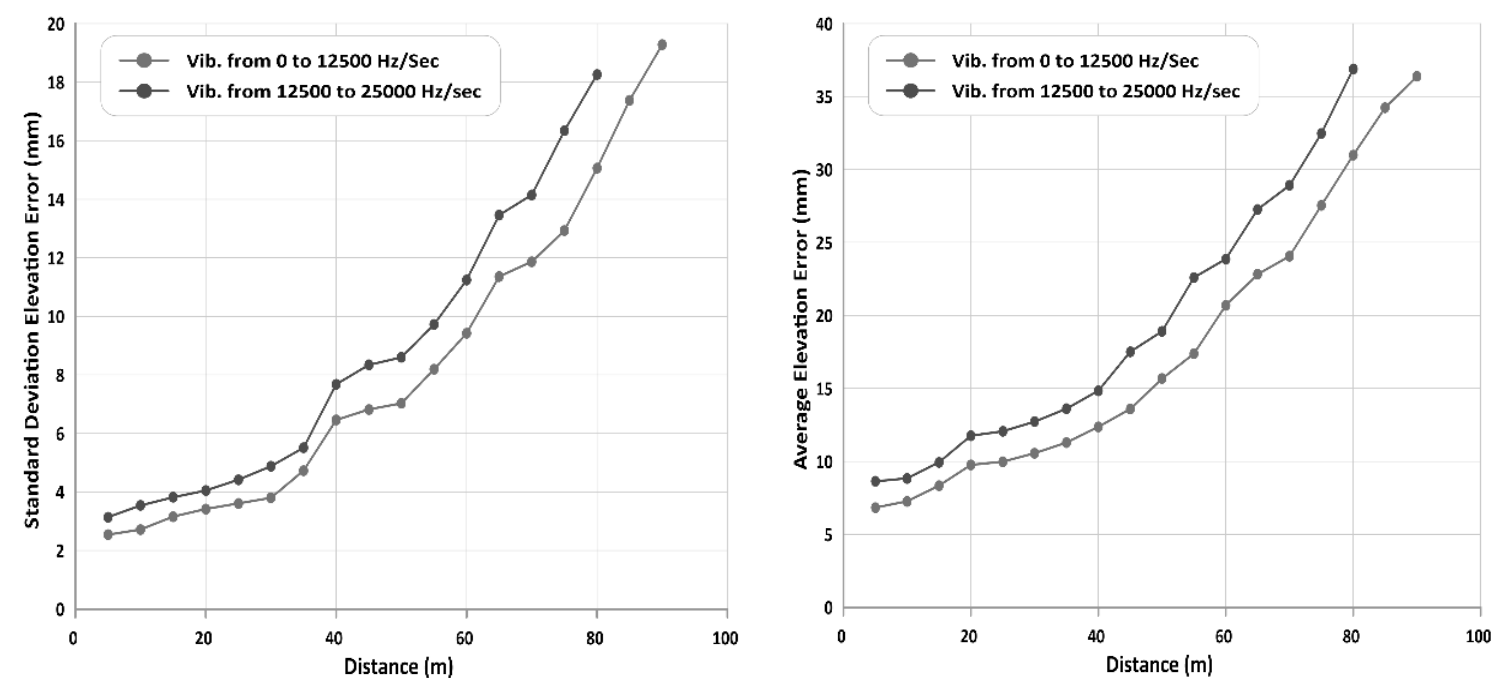

Figure 6. Vibration effect on Average of observations and Standard deviations of digital level at different distances.

In the first stage of vibration (from 0 to $12500 \mathrm{HZ} / \mathrm{Sec}$.), the observation distance is limited with $90 \mathrm{~m}$ and in the second stage of vibration (from 12500 to $25000 \mathrm{~Hz} / \mathrm{sec}$.), $80 \mathrm{~m}$ is the limit. When the levels of vibrations increase, the average and standard deviation errors increased particularly at long distances. These errors are caused by the uncertainty of the sight line, which records the observation through the barcode staff, which happened in these instruments, in which the digital level (Sokkia SDL30) and the total station (SOKKIA CX-105) contain a pendulum compensator that is used to maintain the instrument horizon .The compensator works to correct the optical path depending on the gravitational property and the optical pathway to its horizontal plane, after an operator completes the levelling with a bull's eye bubble. But it was found out through the experimental tests that the vibration affects the accuracy of observation results because the vibration caused changes in the instruments horizontal plane. It was noticed that these errors may extend to many centimeters. Because this compensator works within a very small field, therefore, some errors remain even after correction. The trend line equations, correlation, and the coefficient of determination were calculated for each chart and each condition of observation as shown in table 5.

Table 5. The trend line equations, correlation, and the coefficient of determination for observations error resulting from the chart.

\begin{tabular}{|c|c|c|c|}
\hline Observations conditions & $\begin{array}{c}\text { Trend line equations of errors, } \\
\text { where } \mathbf{D} \text { is Distance in }(\mathbf{m})\end{array}$ & $\begin{array}{c}\text { The correlation between } \\
\text { Distance and the } \\
\text { average elevation error }\end{array}$ & $\begin{array}{c}\text { Coefficient of } \\
\text { determination }\end{array}$ \\
\hline $\begin{array}{c}\text { Stage 1 Vibration (from 0 to } \\
12500 \mathrm{~Hz} / \mathrm{Sec} .)\end{array}$ & Error $=(1.3577+0.3454 \mathrm{D}) \mathrm{mm}$ & $\mathrm{R}=0.96554$ & $\mathrm{R}^{2}=0.9323$ \\
\hline $\begin{array}{c}\text { Stage 2 Vibration (from } \\
12500 \text { to } 25000 \mathrm{~Hz} / \mathrm{Sec} .)\end{array}$ & Error $=(3.427+0.3618 \mathrm{D}) \mathrm{mm}$ & $\mathrm{R}=0.96864$ & $\mathrm{R}^{2}=0.9383$ \\
\hline
\end{tabular}



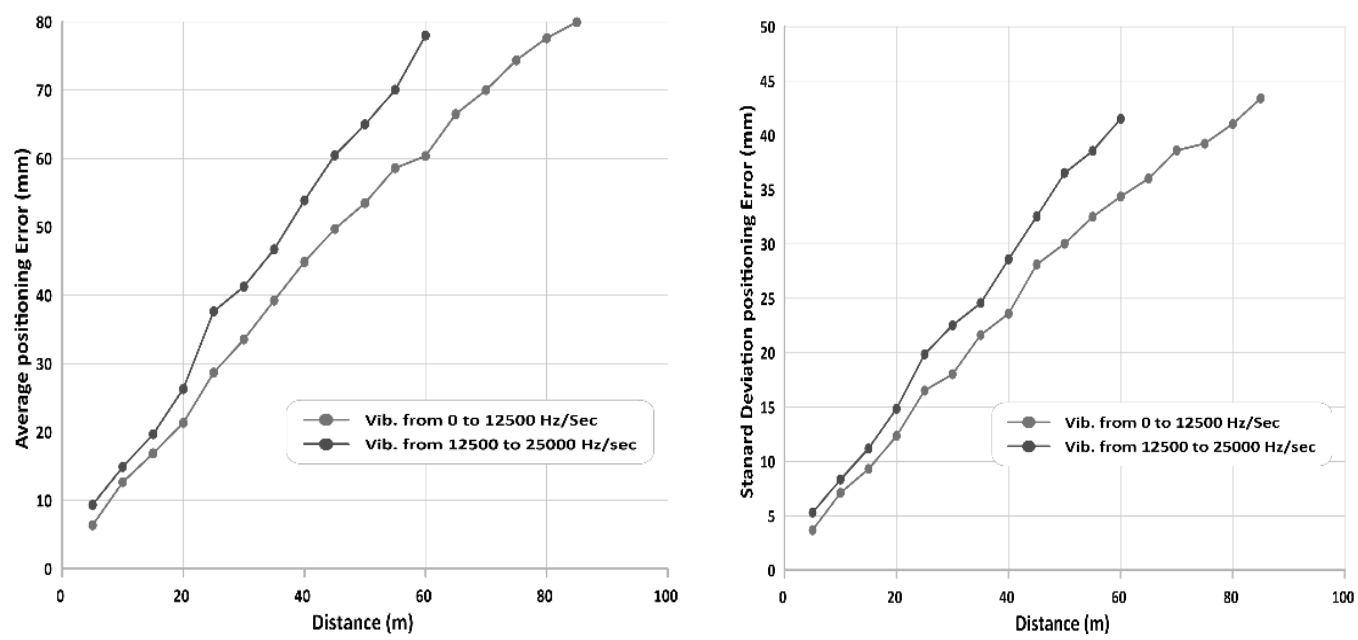

Figure 7. A reflector-less prism Average of observations and Standard deviations of observations (mm) affected by vibrations at different distances.

Figures 7 shows the average and standard deviations of Positioning observations using the reflector-less prism. 79.95 and $43.41 \mathrm{~mm}$ were the maximum values at $85 \mathrm{~m}$ through stage 1 (from 0 to $12500 \mathrm{~Hz} / \mathrm{sec}$.), and the maximum observed distances were 85 and $60 \mathrm{~m}$ at the two vibration levels from 0 to $12500 \mathrm{~Hz} / \mathrm{sec}$. and from 12500 to 25000 $\mathrm{Hz} / \mathrm{sec}$. Figure 7 illustrates the variance between the average and standard deviation error in Positioning; they recorded their highest levels in stage 1 (from 0 to $12500 \mathrm{~Hz} / \mathrm{sec}$.), and the changes between them were almost close at distances from 5 to $35 \mathrm{~m}$. And the trend line equations for charts for each condition are shown in table 6 .

Table 6. The trend line equations, correlation, and the coefficient of determination for observations error resulting from the chart.

\begin{tabular}{|c|c|c|c|}
\hline $\begin{array}{c}\text { Observations } \\
\text { conditions }\end{array}$ & $\begin{array}{c}\text { Trend line equations of errors, } \\
\text { where D is Distance in }(\mathbf{m})\end{array}$ & $\begin{array}{c}\text { The correlation between } \\
\text { Distance and the average } \\
\text { positioning error }\end{array}$ & $\begin{array}{c}\text { Coefficient of } \\
\text { determination }\end{array}$ \\
\hline $\begin{array}{c}\text { Stage } 1 \text { Vibration (from } \\
0 \text { to } 12500 \mathrm{~Hz} / \mathrm{Sec} .)\end{array}$ & Error $=(4.5657+0.9367 \mathrm{D}) \mathrm{mm}$ & $\mathrm{R}=0.99599$ & $\mathrm{R}^{2}=0.992$ \\
\hline $\begin{array}{c}\text { Stage } 2 \text { Vibration (from } \\
12500 \text { to } 25000 \mathrm{~Hz} / \mathrm{Sec} .)\end{array}$ & Error $=(2.8488+1.2539 \mathrm{D}) \mathrm{mm}$ & $\mathrm{R}=0.99779$ & $\mathrm{R}^{2}=0.9956$ \\
\hline
\end{tabular}

\section{Sunlight Direction test result}

For Digital Level SOKKIA SDL-30, the absolute maximum and minimum error of elevation besides the absolute average error and the standard deviation error of elevation were calculated.

The average error and the standard deviation in elevation were presented in figure 8 in the sun direction and opposite to sun direction. 

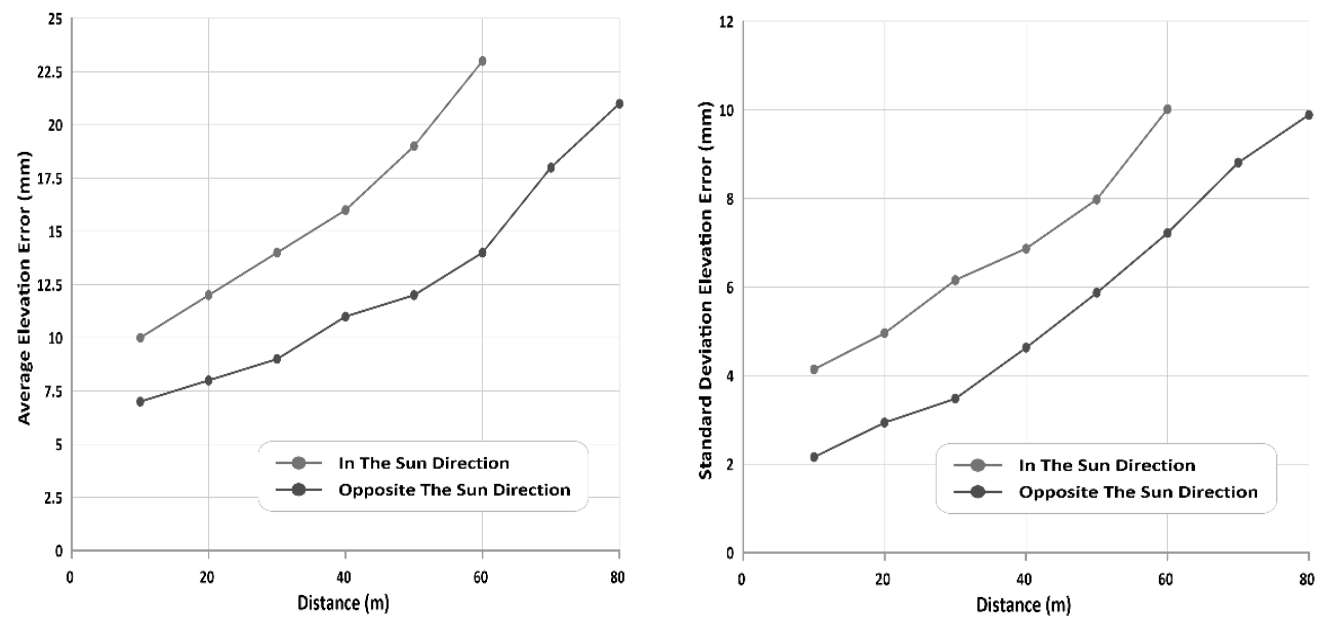

Figure 8. Sun direction effect on Average of observations and Standard deviations of digital level at different distances.

The average error besides the standard deviation error increased at all measured distances in the sun direction when compared to the error at the same distances for the opposite direction.

The maximum average error and standard deviation error obtained at distance $60 \mathrm{~m}$ recording are 23 and $10 \mathrm{~mm}$ in the sun direction, where the increase in these two errors reached $64.3 \%$, and $38.8 \%$, respectively. This error effect could be referred to the high levels of brightness because of facing the sunlight beams, which lead to errors in readings. Both Digital level (SOKKIA SDL-30) and Total station (SOKKIA CX-105) during observing process depend on sending an infrared radiation during monitoring process, which reaches the observed point but with the experimental test, it was noticed that these instruments are in the direction of the sun, and the sun's rays affect this infrared ray and change its path, which in turn affect the accuracy of these digital instruments during the monitoring process (Algarni\& Ali, 1998; Beshr \& Abo Elnaga, 2011).

In addition, the trend line equation, correlation, and the coefficient of determination for charts for each condition are shown in table 7.

Table 7. The trend line equations, correlation, and the coefficient of determination for observations error resulting from the chart.

\begin{tabular}{|c|c|c|c|}
\hline $\begin{array}{c}\text { Observations } \\
\text { conditions }\end{array}$ & $\begin{array}{c}\text { Trend line equations of errors, } \\
\text { where } \mathbf{D} \text { is Distance in }(\mathbf{m})\end{array}$ & $\begin{array}{c}\text { The correlation between } \\
\text { Distance and the average } \\
\text { elevation error }\end{array}$ & $\begin{array}{c}\text { Coefficient of } \\
\text { determination }\end{array}$ \\
\hline $\begin{array}{c}\text { In the Sun } \\
\text { Direction }\end{array}$ & Error $=(6.8667+0.2514 \mathrm{D}) \mathrm{mm}$ & $\mathrm{R}=0.98799$ & 0.9761 \\
\hline $\begin{array}{c}\text { Opposite the sun } \\
\text { direction }\end{array}$ & Error $=(3.7143+0.1952 \mathrm{D}) \mathrm{mm}$ & $\mathrm{R}=0.97043$ & $\mathrm{R}^{2}=0.9417$ \\
\hline
\end{tabular}

For total station (SOKKIA CX-105), the average and the standard deviation errors in positioning use the reflectorless total station.

The total station cannot be observed beyond a distance of $90 \mathrm{~m}$ in the sun direction.

The effect of sunlight position on the average and standard error for a reflector-less prism total station is shown in 
Figure 8, 9 respectively. The major observation is the increase of the two calculated average and standard errors with exposing the instrument to the Sunlight compared to its opposite direction to the sun, for all observed distances.

The maximum obtained distances were 90 and $100 \mathrm{~m}$ for sun direction with and opposite to the reading direction, respectively.
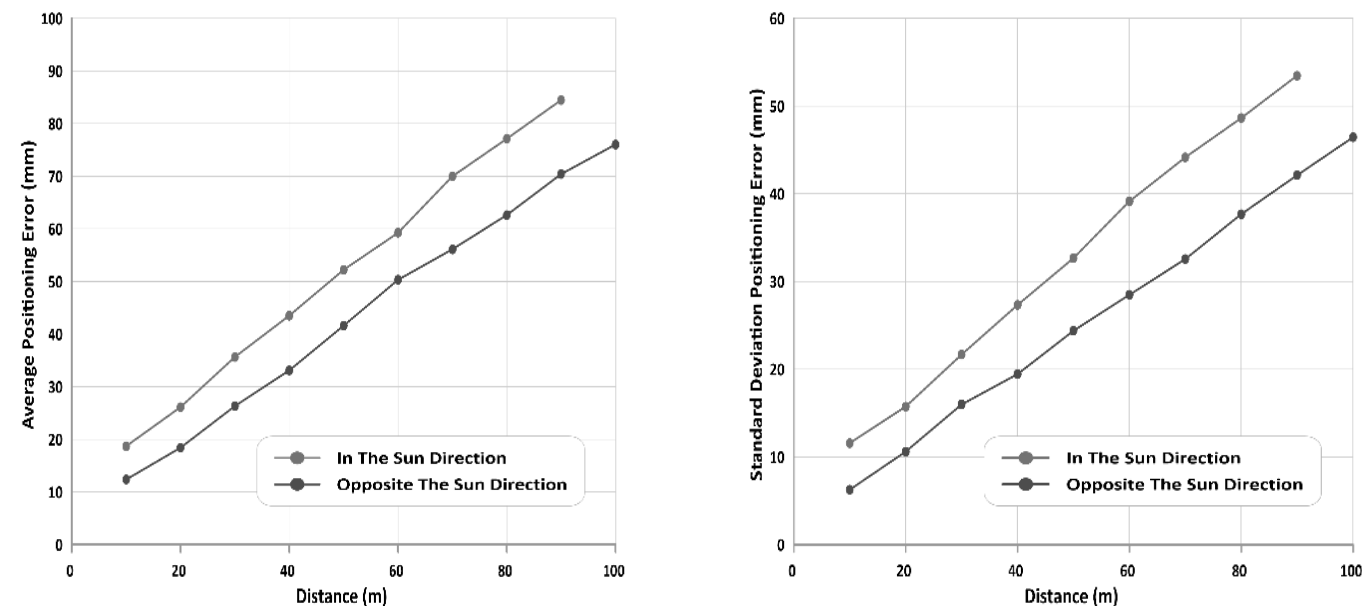

Figure 9. A reflector-less prism Average of observations and Standard deviations of observations (mm) affected by the sun direction at different distances.

At the maximum observed distance, the average and standard error recorded were 84.48 and $53.47 \mathrm{~mm}$, respectively, for reading in the sun direction and 76.03 and $46.44 \mathrm{~mm}$ for observed distance opposite to sun direction at observed distance $100 \mathrm{~m}$.

The maximum increase in average and standard deviation error was 51.25 and $84.7 \%$ with respect to the observation with and opposite to the sun direction, and the trend line equation, correlation, and the coefficient of determination for charts for each condition are shown in table 8 .

Table 8. The trend line equations, correlation, and the coefficient of determination for observations error resulting from the chart.

\begin{tabular}{|c|c|c|c|}
\hline $\begin{array}{c}\text { Observations } \\
\text { conditions }\end{array}$ & $\begin{array}{c}\text { Trend line equations of errors, where } \\
\text { D is Distance in }(\mathbf{m})\end{array}$ & $\begin{array}{c}\text { The correlation between } \\
\text { Distance and the average } \\
\text { positioning error }\end{array}$ & $\begin{array}{c}\text { Coefficient of } \\
\text { determination }\end{array}$ \\
\hline $\begin{array}{c}\text { In the Sun } \\
\text { Direction }\end{array}$ & Error $=(10.194+0.8341 \mathrm{D}) \mathrm{mm}$ & $\mathrm{R}=0.99946$ & $\mathrm{R}^{2}=0.9989$ \\
\hline $\begin{array}{c}\text { Opposite the sun } \\
\text { direction }\end{array}$ & Error $=(4.8647+0.7249 \mathrm{D}) \mathrm{mm}$ & $\mathrm{R}=0.999$ & $\mathrm{R}^{2}=0.9982$ \\
\hline
\end{tabular}

\section{Temperature Test result}

For Digital Level (SOKKIA SDL-30), the absolute average error and the standard deviation error were calculated. Figure 10 illustrates the change in average and standard deviation error due to the increase in temperature. 

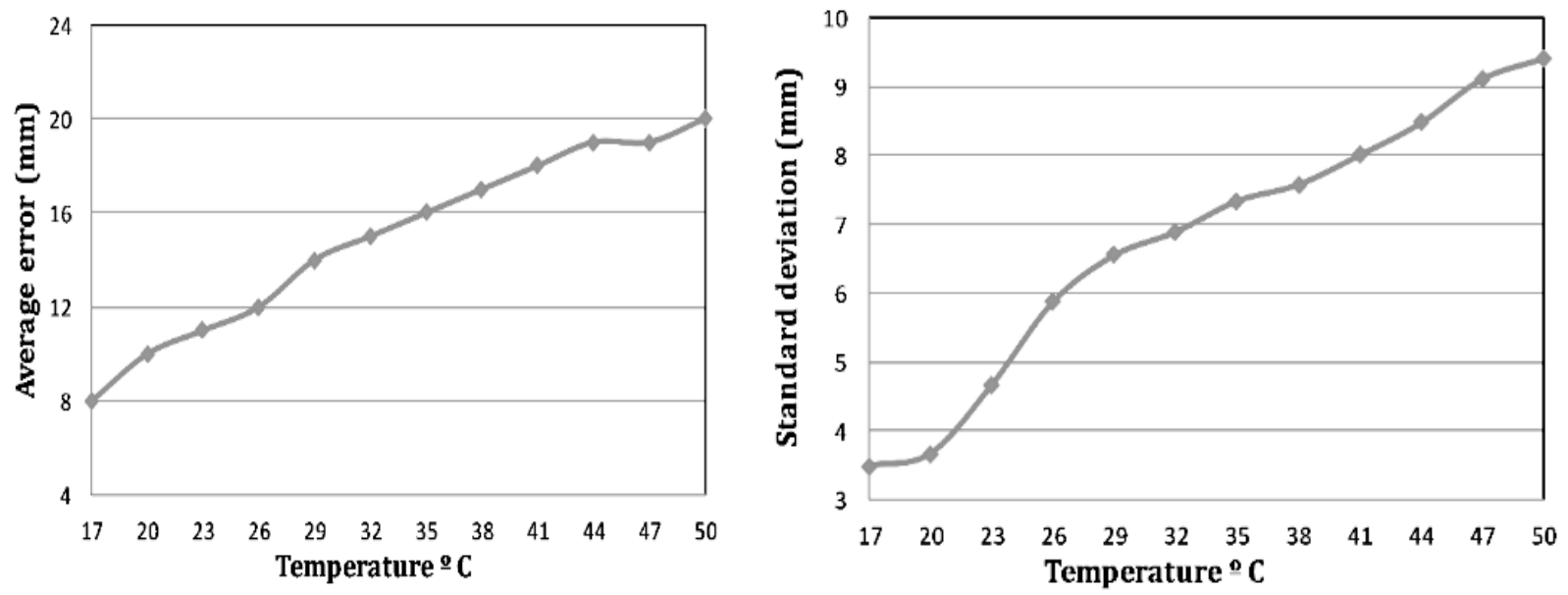

Figure 10. Average error $(\mathrm{mm})$ and Standard deviation of error $(\mathrm{mm})$ using digital level at different temperatures.

The higher the temperature, the higher the average, and the higher the standard deviation error. The increase in the temperature with $33^{\circ} \mathrm{C}$ leads to an increase in average and standard deviation with 150 and $170.7 \%$, respectively. The effect of the heat leads the measuring light beams to be diverged (Gassner, 2005). Digital level and total station are high-precision instruments that use barcode rods and sensitive charged-coupled device (CCD) linear sensors. To determine the height difference, it is necessary to bring the line of sight to the horizontal position. Horizontality of the line of sight is achieved by the compensator. The sensitive charged-coupled device is affected by the temperature change, which leads to an error in calibration by changing the line of sight and making changes in the accuracy of the digital surveying instruments (Gucević, J., Delčev, S., \& Ogrizović, V., 2011).

In addition, the trend line equation, correlation, and the coefficient of determination for charts for each condition are shown in table 9.

Table 9. The trend line equations, correlation, and the coefficient of determination for observations error resulting from the chart.

\begin{tabular}{|c|c|c|c|}
\hline $\begin{array}{c}\text { Observations } \\
\text { conditions }\end{array}$ & $\begin{array}{c}\text { Trend line equations of errors, where } \\
\mathbf{T} \text { is Temperature in }{ }^{\circ} \mathbf{C}\end{array}$ & $\begin{array}{c}\text { The correlation between } \\
\text { Temperature and the } \\
\text { average elevation error }\end{array}$ & $\begin{array}{c}\text { Coefficient of } \\
\text { determination }\end{array}$ \\
\hline $\begin{array}{c}\text { Temperature set } \\
\text { from } 17^{\circ} \mathrm{C} \text { to } \\
50^{\circ} \mathrm{C}\end{array}$ & Error $=(2.852+0.3601 \mathrm{~T}) \mathrm{mm}$ & $\mathrm{r}=0.9882$ & $\mathrm{R}^{2}=0.9766$ \\
\hline
\end{tabular}

For total station (SOKKIA CX-105), the average error in positioning and the standard deviation in positioning for the reflector-less total station were calculated, and they are shown in figure 11. As shown in figure 11, it is clearly noticed that the change in both average and standard deviation error is almost directly proportional to the increase in the temperature. 

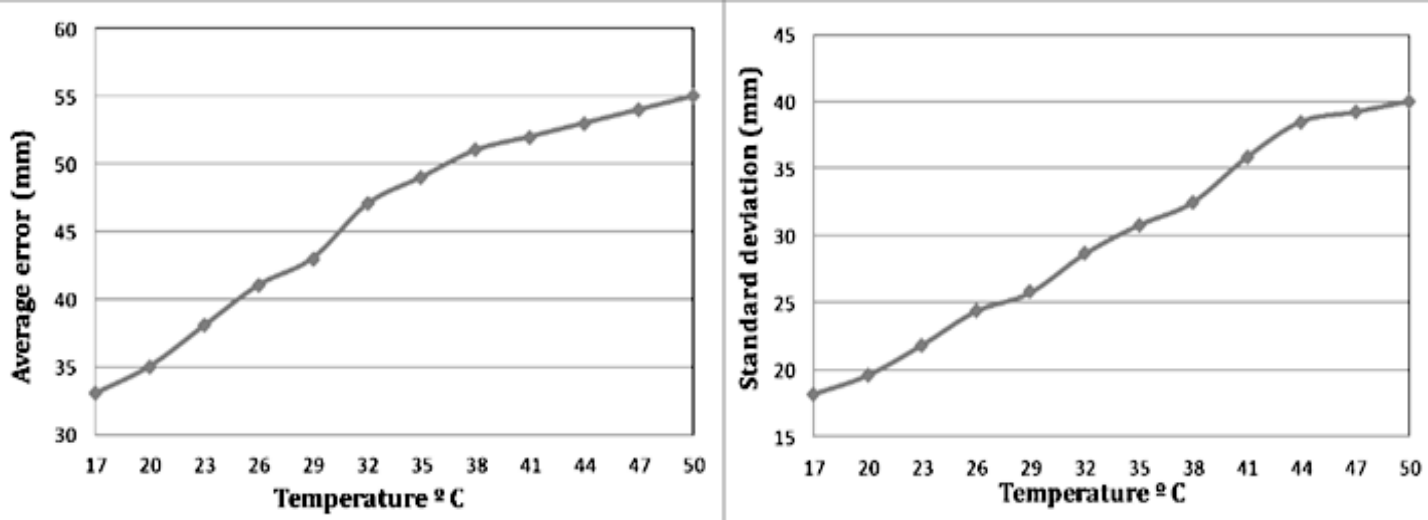

Figure 11. Average of error $(\mathrm{mm})$ and Standard deviation of the reflector-less total station at different temperatures.

The increase in temperature from $17{ }^{\circ} \mathrm{C}$ to $50^{\circ} \mathrm{C}$ leads to an increase in both average and standard deviation with 66.67 and $119.47 \%$ from their origin value at $17^{\circ} \mathrm{C}$.

These results are compatible with the results obtained by Pašagić, Risović (2003), and the trend line equation, correlation, and the coefficient of determination for charts for each condition are shown in table 10.

Table 10. The trend line equations, correlation, and the coefficient of determination for observations error resulting from the chart.

\begin{tabular}{|c|c|c|c|}
\hline $\begin{array}{c}\text { Observations } \\
\text { conditions }\end{array}$ & $\begin{array}{c}\text { Trend line equations of errors, where } \\
\mathbf{T} \text { is Temperature in }{ }^{\circ} \mathbf{C}\end{array}$ & $\begin{array}{c}\text { The correlation between } \\
\text { Temperature and the } \\
\text { average positioning error }\end{array}$ & $\begin{array}{c}\text { Coefficient of } \\
\text { determination }\end{array}$ \\
\hline $\begin{array}{c}\text { Temperature set } \\
\text { from } 17^{\circ} \mathrm{C} \text { to } 50^{\circ} \mathrm{C}\end{array}$ & Error $=(22.529+0.6981 \mathrm{~T}) \mathrm{mm}$ & $\mathrm{R}=0.9801$ & $\mathrm{R}^{2}=0.9607$ \\
\hline
\end{tabular}

\section{Battery Charge Test result}

Figure 12 shows the change in elevation error with respect to discharging time; it can be clearly noticed that spending more time in working leads to an obvious increase in elevation error especially when observing more far distances.

The maximum elevation error reached $0.08 \mathrm{~m}$, which is obtained at observation distance $50 \mathrm{~m}$ with operating the instrument for 8 hours.

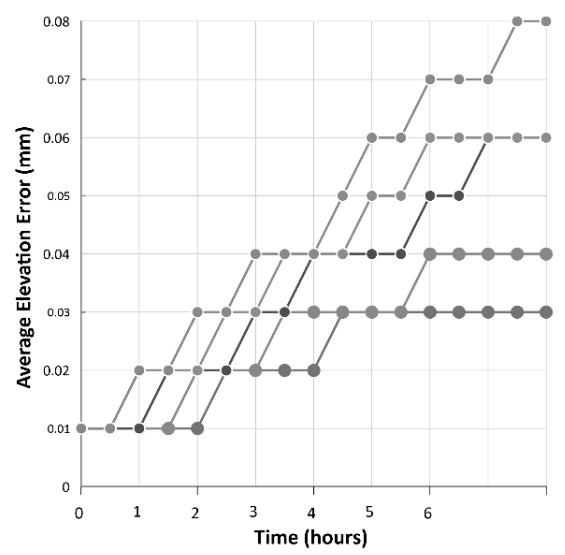

Figure 12. The effect of battery capacity on the elevation error of the digital level. 
The elevation error for working time more than 5 hours seems to be constant. Shortage in battery capacity leads to Irregular infrared radiation, which leads to an error in calibration by changing in the line of sight and making changes in the accuracy of the digital surveying instruments (Algarni \& Ali, 1998; Beshr \& Abo Elnaga, 2011; Fawzy, 2015).

The trend line equation, correlation, and the coefficient of determination for charts for each condition are shown in table 11 .

Table 11. The trend line equations, correlation, and the coefficient of determination for observations error resulting from the chart.

\begin{tabular}{|c|c|c|c|}
\hline Observations conditions & $\begin{array}{c}\text { Trend line equations of errors, } \\
\text { where }(\mathbf{t}) \text { is time in (hours) }\end{array}$ & $\begin{array}{c}\text { The correlation between } \\
\text { Time and the average } \\
\text { elevation error }\end{array}$ & $\begin{array}{c}\text { Coefficient of } \\
\text { determination }\end{array}$ \\
\hline $\begin{array}{c}(10 \mathrm{~m}) \text { Distance between the } \\
\text { digital level and the coded staff }\end{array}$ & Error $=(0.0088+.0032 \mathrm{t}) \mathrm{mm}$ & $\mathrm{R}=0.92527$ & $\mathrm{R}^{2}=0.8561$ \\
\hline $\begin{array}{c}(20 \mathrm{~m}) \text { Distance between the } \\
\text { digital level and the coded staff }\end{array}$ & Error $=(0.0086+0.0045 \mathrm{t}) \mathrm{mm}$ & $\mathrm{R}=0.9848$ & $\mathrm{R}^{2}=0.9275$ \\
\hline $\begin{array}{c}(30 \mathrm{~m}) \text { Distance between the } \\
\text { digital level and the coded staff }\end{array}$ & Error $=(0.0071+0.0069 \mathrm{t}) \mathrm{mm}$ & $\mathrm{R}=0.979$ & $\mathrm{R}^{2}=0.9585$ \\
\hline $\begin{array}{c}(40 \mathrm{~m}) \text { Distance between the } \\
\text { digital level and the coded staff }\end{array}$ & Error $=(0.0104+0.0071 \mathrm{t}) \mathrm{mm}$ & $\mathrm{R}=0.9908$ & $\mathrm{R}^{2}=0.9818$ \\
\hline $\begin{array}{c}(50 \mathrm{~m}) \text { Distance between the } \\
\text { digital level and the coded staff }\end{array}$ & Error $=(0.0086+0.0093 \mathrm{t}) \mathrm{mm}$ & & $\mathrm{R}$ \\
\hline
\end{tabular}

Figure 13 illustrates the effect of discharging the battery on the performance of the reflector-less total station. The increase in the observed distance leads to an increase in the elevation error at all levels of battery. As the time increases, the battery discharges, and the elevation error increases rapidly, especially when the distance observed exceeded $30 \mathrm{~m}$ after 3 working hours.

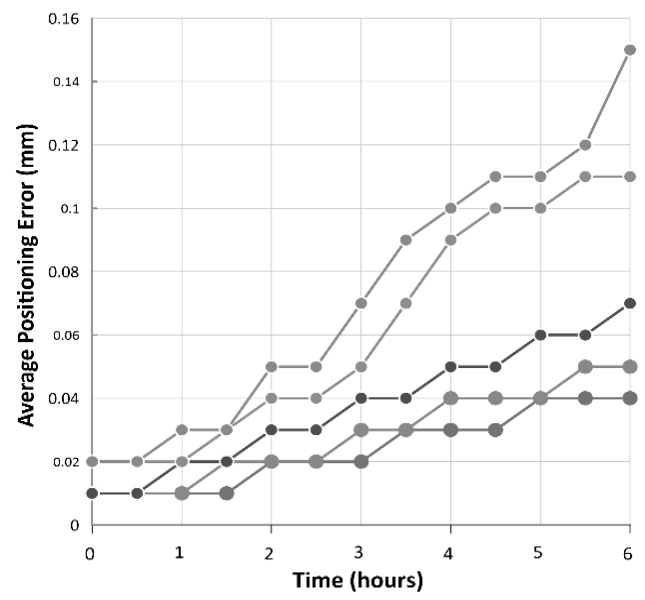

Figure 13. The effect of battery capacity on the elevation error of the reflector-less total station.

The elevation error reaches its summit when $50 \mathrm{~m}$ is observed after 6 working hours with $0.15 \mathrm{~m}$ error in elevation (Fawzy, 2015). 
The trend line equations, correlation, and the coefficient of determination for charts for each condition are shown in table 12.

Table 12. The trend line equations, correlation, and the coefficient of determination for observations error resulting from the chart.

\begin{tabular}{|c|c|c|c|}
\hline Observations conditions & $\begin{array}{c}\text { Trend line equations of errors, } \\
\text { where }(\mathrm{t}) \text { is time in (hours) }\end{array}$ & $\begin{array}{c}\text { The correlation between } \\
\text { Time and the average } \\
\text { positioning error }\end{array}$ & $\begin{array}{c}\text { Coefficient of } \\
\text { determination }\end{array}$ \\
\hline $\begin{array}{c}(10 \mathrm{~m}) \text { Distance between the total } \\
\text { station and the reflector-less }\end{array}$ & Error $=(0.006+.0 .0059 \mathrm{t}) \mathrm{mm}$ & $\mathrm{R}=0.9686$ & $\mathrm{R}^{2}=0.9382$ \\
\hline $\begin{array}{c}(20 \mathrm{~m}) \text { Distance between the total } \\
\text { station and the reflector-less }\end{array}$ & Error $=(0.0064+0.0074 \mathrm{t}) \mathrm{mm}$ & $\mathrm{R}=0.9798$ & $\mathrm{R}^{2}=0.96$ \\
\hline $\begin{array}{c}(30 \mathrm{~m}) \text { Distance between the total } \\
\text { station and the reflector-less }\end{array}$ & Error $=(0.0077+0.01 \mathrm{t}) \mathrm{mm}$ & $\mathrm{R}=0.9826$ \\
\hline $\begin{array}{c}(40 \mathrm{~m}) \text { Distance between the total } \\
\text { station and the reflector-less }\end{array}$ & Error $=(0.0071+0.0181 \mathrm{t}) \mathrm{mm}$ & $\mathrm{R}^{2}=0.9486$ \\
\hline $\begin{array}{c}(50 \mathrm{~m}) \text { Distance between the total } \\
\text { station and the reflector-less }\end{array}$ & Error $=(0.0078+0.0218 \mathrm{t}) \mathrm{mm}$ & $\mathrm{R}=0.9833$ & $\mathrm{R}^{2}=0.9669$ \\
\hline
\end{tabular}

\section{CONCLUSION}

The influences of the vibration, temperature, solar direction, and battery charge on the digital level Model SOKKIA SDL-30 and total station Model SOKKIA CX-105 instruments were noticed to be highly affecting the instruments performance.

- Vibration affects the accuracy of observation results, because the vibration caused changes in the instruments horizontal plane and those are noticed by experimental tests, and many errors may extend for too many centimetres.

- Vibration has a direct relationship with the average error and standard deviation errors of observations for the digital level and the total Station.

- The maximum distances of observations for Digital level to the codded staff through two stages of vibration from 0.0 to 12500 and from 12500 to $25000 \mathrm{~Hz} / \mathrm{sec}$ were 90 and $80 \mathrm{~m}$, respectively.

- $44,36.89$, and $18.26 \mathrm{~mm}$ were the maximum, average, and standard deviation error in elevation when the distance between the instrument and bar code is $80 \mathrm{~m}$ through exposure to vibration (from 12500 to $25000 \mathrm{~Hz} / \mathrm{sec}$ ).

- The average and the standard deviations elevation error for the digital level increased by 2 times at $80 \mathrm{~m}$ distance, and the average and the standard deviations positioning error increased 3 times for the total station using the reflector-less prism at $80 \mathrm{~m}$ distance between the instrument and bar code through an artificial vibration up to $25000 \mathrm{HZ} / \mathrm{SC}$.

- The maximum distances observed by the total station with the reflector-less prism were $60 \mathrm{~m}$ and through exposure to vibration from 12500 to $25000 \mathrm{~Hz} / \mathrm{sec}$, the standard deviation of the positioning was $41.51 \mathrm{~mm}$.

- The sun's rays affect the infrared ray in monitoring process and change their paths, which in turn affect the accuracy of the digital surveying instruments.

- For digital level Model SOKKIA SDL-30, the maximum average error and standard deviation error obtained at 
distance $60 \mathrm{~m}$ recording are 23 and $10 \mathrm{~mm}$ in the sun direction, where the increase in these two errors reaches $64.3 \%$ and $38.8 \%$, respectively.

- The total station cannot be observed beyond a distance of $90 \mathrm{~m}$, by using the reflector-less prism in the sun direction.

- The maximum increase in average and standard deviation error was 51.25 and $84.7 \%$ with respect to the observation with and opposite to the sun direction at a distance $100 \mathrm{~m}$ using a reflector-less prism.

- The temperature change affects the sensitive charged-coupled device inside surveying instruments, which leads to an error in calibration by changing the line of sight and making changes in the accuracy of the digital surveying instruments.

- For digital level Model SOKKIA SDL-30, the increase in the temperature with 33oC leads to increase in average and standard deviation with 150 and $170.7 \%$, respectively.

- For total Station Model SOKKIA CX-105 with reflector-less prism, the increase in temperature from $17^{\circ} \mathrm{C}$ to $50^{\circ} \mathrm{C}$ leads to an increase in both average and standard deviation with 66.67 and $119.47 \%$ from their origin value at $17^{\circ} \mathrm{C}$.

- Shortage in battery capacity leads to irregular infrared radiation, which leads to an error in calibration by changing the line of sight and making changes in the accuracy of the digital surveying instruments.

- For the digital level, the maximum elevation error was obtained at observation distance $8 \mathrm{~h}$ with $0.08 \mathrm{~m}$. The elevation error for working time more than 5 hours seems to be constant.

- For the Total Station Model SOKKIA CX-105 with reflector-less prism, the elevation error reaches its summit when $50 \mathrm{~m}$ is observed after 6 working hours with $0.15 \mathrm{~m}$ error in elevation.

\section{REFERENCES}

Adinew, R. \& Damtie,B., 2012. Accuracy analysis and Calibration of Total Station based on the Reflectorless Distance Measurement.

Algarni, D.A. \& Ali, A.E. (1998). Heighting and Distance Accuracy with Electronic Digital Levels. Journal of King Saud University - Engineering Sciences, 10(2): 229-239.

Arseni, M., Georgescu, L. \& Circiumaru, L., 2015. The influence of the atmospheric temperature value on the accuracy of distance measurement with the surveying total station, ANNALS OF "DUNAREA DE JOS" UNIVERSITY OF GALATI FASCICLE II,

Beshr, A.A.A. \& Abo Elnaga, I.M., 2011. Investigating the Accuracy of Digital Levels and Reflectorless Total Stations for Purposes of Geodetic Engineering, Alexandria Engineering Journal, vol. 50, no. 4, pp. 399-405.

Elhassan, I.M. \& Ali, A.S., 2011. Comparative Study of Accuracy in Distance Measurement Using : Optical and Digital Levels, Journal of King Saud University - Engineering Sciences, vol. 23, no. 1, pp. 15-19.

Fawzy, H.E., 2015. Evaluate the accuracy of reflector-less total station, IJCIET, pp. 23-30,

Gassner, G., 2005. Investigations of digital levels at the SLAC vertical comparator.

Geethalankara, A., Rupasinghe, A.R. \& Niriella, N.S.C., 2016. Studying the Factors Affect for the Accuracy of Reflectorless Total Station Observations, Proceedings in Engineering, Built Environment and Spatial Sciences, 9th International Research Conference-KDU, Sri Lanka 2016.

Glaser D. \& Friston K., 2004. Variance Components. Human Brain Function 781-91.

Gučević, J., Delčev, S. \& V.O. 2011. Determining Temperature DEPENDENCE OF COLLIMATION ERROR OF DIGITAL LEVEL LEICA DNA 03 Србија, FIG Working Week 2011 Bridging the Gap between Cultures Marrakech, Morocco, no. May, pp.

Gučević, J., Miljković, S., Delčev, S. \& Ogrizović, V., 2017. Effects of Low Temperatures in the Line of Sight of Digital Levels, 
Journal of Surveying Engineering, vol. 143, no. 2, pp. 1-7.

Jeon, B.G., Kim, N.S. \& Kim, S.I. 2015. Estimation of the vibration serviceability deflection limit of a high-speed railway bridge considering the bridge-train interaction and travel speed. KSCE Journal of Civil Engineering, 20(2): 747-761.

Kamps, M., 2018. THE EFFECT OF THE RESOLUTION OF TOPOGRAPHY DESCRIPTION ON 2-D MODELLING OF RIVER HABITAT. the Faculty of Engineering and the Built Environment, University of the Witwatersrand, Johannesburg, Msc.

Khalil R., 2007. Enlargement the sighting distance of Sokkia Digital Level SDL30. In: Quality of measurements. Strategic Integration of Surveying Services FIG Working Week, Hong Kong SAR, China . 13-17.

Kim, J., Kwon, S., Park, S. \& Kim, Y, 2013. A MEMS-based commutation module with vibration sensor for wireless sensor network-based tunnel-blasting monitoring. KSCE Journal of Civil Engineering, 17(7): 1644-1653.

Ko, J.M. \& Y.Q. Ni. 2003. Structural Health Monitoring and Intelligent Vibration Control of Cable-Supported Bridges: Research and Application. KSCE Journal of Civil Engineering 7: 701-716.

Kowalczyk, K. \& Rapinski, J. 2014. Investigating the Error Sources in Reflectorless EDM, Journal of Surveying Engineering, vol. 140, no. 4, p. 06014002.

Kudryavtsev, S., Kazharsky, A., Yedigaryan, A. \& Goncharova, E., 2018. Geotechnical Justification and Monitoring of Subterranean Parking Construction in Khabarovsk City, MATEC Web of Conferences 193, A. Mottaeva and B. Melovi, ed., EDP Sciences, p. 03039.

Labuz \& Tomasz A., 2016. A Review of Field Methods to Survey Coastal Dunes-experience Based on Research from South Baltic Coast. Journal of Coastal Conservation.

Li, L., Tan, L. \& Wang, D., 2018. The influence of flywheel micro vibration on space camera and vibration suppression. Mechanical Systems and Signal Processing, 100: 360-370.

Mohamed, A. \& Nasreldin M., 2018. Design and Simulation of a Compensator for Automatic-Optical Leveling Instrument. International Conference on Computer, Control, Electrical, and Electronics Engineering (ICCCEEE).

Murariu, G., Hahuie, V. \& Georgescu, L., 2017. Study on the Influence of Atmospheric Parameters on the Accuracy of the Geodetic Measurements, TIM15-16 Physics Conference, AIP Publishing.

Nasution, T.H., Muchtar, M.A., Siregar, I., Andayani, U., Christian, E. \& Sinulingga, E. P., 2017. Electrical appliances control prototype by using GSM module and Arduino. 2017 4th International Conference on Industrial Engineering and Applications (ICIEA).

Nasreldin M.A., M. (2018). Design and Simulation of a Compensator for Automatic-Optical Leveling Instrument. 2018 International Conference on Computer, Control, Electrical, and Electronics Engineering (ICCCEEE)

Pašagić, V. \& Risović, T. 2003. The Influence of temperature and pressure on performance of optical surveying instruments, XVII IMEKO World Congress Metrology in the 3rd Millennium, Dubrovnik, Croatia.

Patel, V. \& Patel, M., 2017. Development of smart sensing unit for vibration measurement by embedding accelerometer with the Arduino microcontroller. Int. J. Instrum. Sci 7: 1-7.

Pellegrinelli, A., Furini, A., Bonfè, M. \& Russo, P. 2013. Motorised digital levels: development and applications. Survey Review, 45(330): 174-189.

Rekus, D., Aksamitauskas, V.C. \& Giniotis, V., 2008. Application of Digital Automatic Levels and Impact of Their Accuracy on Construction Measurements. The 25th International Symposium on Automation and Robotics in Construction.

Safrel, Ispen, Julianto,E. \& Usman,N., 2018. Accuracy Comparison between GPS Real Time Kinematic (RTK) Method and Total Station to Determine the Coordinate of an Area. Jurnal Teknik Sipil Dan Perencanaan.

Teunissen, P.J.G. \& A.R. Amiri-Simkooei. 2007. Least-Squares Variance Component Estimation. Journal of Geodesy 82: 65-82.

Yadesh, V. \& K. Venkatachalam. 2016. GSM Based Industrial Appliances Control Using Arduino Processor. International Journal of Science and Research (IJSR) 5: 1680-1682.

Zhao, N., Li, X. \& Liu, Y. 2018. Research and Design of Night Electronic Pet Clothing. Proceedings of the 2018 5th International Conference on Education, Management, Arts, Economics and Social Science (ICEMAESS 2018) 